\title{
“DEVONU LUGOTIT TURK” AND UZBEK DIALECTS
}

\author{
Bakhtiyor Abdushukurov
}

Professor, Tashkent State University Of Uzbek Language And Literature Named After Alisher Navoi, Uzbekistan

\section{ABSTRACT}

The article examines "Devonu lugotit turk" and Uzbek dialects, and acknowledges Mahmud Kashgari's special services in this regard. The valuable importance of "Devon" in dialectology is highlighted. Each example is explained based on the lexemes available in the fraternal peoples, effectively using a number of linguistic methods, such as comparative, comparative-historical. The commonalities and differences related to the reflection of words in the dialects and their presentation in Devon are analyzed.

KEYWORDS: - Dialect, dialectology, phonetic changes, morphologic changes, etymology of Turkish lexemes, compound words.

\section{INTRODUCTION}

It is known that Mahmud Kashgari, recognized by experts as a great scholar of his time, covered many areas of linguistics in his work "Devonu lug'otit turk". It contains important information on the phonetic, lexical, grammatical, dialectal features of the Turkic languages, in particular, the Uzbek language. In addition, the study of the history of language, its awareness of its old state, is carried out by means of a comparative study of ancient manuscripts, the identification of similarities and differences between them. It should be noted that the monument "Devonu lug'otit turk" has been created for almost ten centuries. Therefore, it is natural that there have been changes in the language. Because during this time the language has undergone phonetic, lexical, morphological, syntactic changes, improved, enriched in accordance with the laws of its development. Our observations of the lexicon of "Devonu lug'otit turk" in relation to today's Uzbek dialects show that there are similarities and some differences between the words used in the memoir language and the dialects, but these are not differences that distinguish them from each other. This can also be observed in the process of comparative analysis performed below.

\section{LITERATURE REVIEW}

Uyghur sources from the Berlin collection, as well as 11th-century monuments, such as the "Devonu lugotit turk", describe the concept of the ayaq as "a glass": Bu ayaqnïn yaruqï bar - the glass has a crack (ДТС,27). In the memoir "Qisasi Rabguziy" the variants of adaq, ayaq, and ayag were used to denote the semen mentioned: Zaiflärni urğanlar İ $\delta i$ azza va

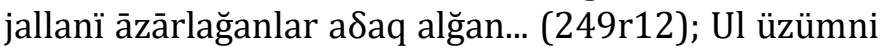
sïqïp suwïn ayaqğa salïp malikkä ayaq tuturdïm 
CURRENT RESEARCH JOURNAL OF PHILOLOGICAL SCIENCES 2(8): 56-61,

May 2021 DOI: https://doi.org/10.37547/philological-crjps-02-08-13

ISSN 2767-3758

(C)2021 Master Journals

Crossref dof 81 Google

Accepted26 ${ }^{\text {th }}$ August, 2021 \& Published $31^{\text {th }}$ August, 2021

(88r14); ...Min sanlïğ harir, idiš ayağlar... (148r18). In the works of Khutb "Khusrav and Shirin" and "Nahjul Farodis" the forms of adaq and ayak are

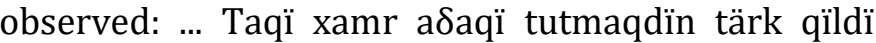
(HФ,133a11); Saqïkar elgi ham taldï ayaqdïn (ХШ,42б2). Although the lexeme of the ayaq is not observed in the Uzbek literary language, its use in the dialect of Lakay living in the Republic of Tajikistan can be found in the "Dictionary of Uzbek Folk Dialects" (ЎХШЛ, 14). There is a view that this word was formed from the ağ noun form of the ay, which means "carved place" in the ancient Turkic language, with the suffix - (a) q, which means "small" (ЎТЭЛ,1,250).

In Mahmud Kashgari's "Devonu lug'otit turk", avut (I, 111), abut means "palm, squeeze": Bir abut ney (I, 85). The lexeme was first used in the "Golden Light" memoir in the form of adut: Ayača aş bermish adutča suv tutmish - a handful of food, a handful of water (ДТС,14).In Yusuf Khos Hajib's epic "Qutadg'u bilig", avuč: Uqušsuz kiši avučča titik - A foolish, ignorant person is like a handful of rubbish (ДТС, 70), avut (ДТС, 71), Tafsir and XIV century Khorezm sources state the form avuč: Bir avuč ušaq taš tutdï taqï...yüzinä atdï (115б1); Bir avuč topraqdïn yarattï (ХШ,117б13). Sāmiriy ul tofraqdïn bir avuč alïb saqlamï̌ erdi (ҚР,126r4). In the works of Alisher Navoi, the term is used in the sense of "palm", "applause" (НАЛ, 478). It appears that by the fifteenth century the meanings of the term had expanded. The term is used in the South Khorezm dialect in the form авыч (ЎХШЛ, 12). This noun is derived from the verb abu-, which means "to take with two hands" in the ancient Turkic language. Later, the following phonetic changes took place in the structure of this word: the consonant $b$ in the vowel range was replaced by the consonant $\mathrm{v}$ : abuč $>$ avuč. In Uzbek, the consonant $h$ is added to the beginning of the term: avuč > havuč (ЎТЭЛ,I,595).

\section{ThE RELATIONS BETWEEN DEVON AND}

\section{DIALECTS}

Mahmud Kashgari describes the lexeme känd under study as follows: Känd is a village in the language of the oghuzs and those close to them. To most Turks, it is a province. That is why Fergana is called Özkänd our city. Samarkand is called Semizkänd because of its size. It is used by the Persians in the style of Samarkand (I, 330). Tärkän is the name of Shosh (Tashkent). Its origin is Tash kand, which means a city built of stone (I, 414).The word first meant "city" in Turfan texts. It turns out that during the Karakhanid period, the term meant "village", "region", "city". In the work "Tafsir" in the forms kend $(39,17)$, kent $(61,9)$ were used in the semantics "village", "city". In "Gulistan bit turkiy" the kent means "city": Bir qul kentgä bardï (30б1). In "Qisasi Rabguziy" there are phonetic variants of the term kend, kent: Yolda kelürdä Aynuš-šams atlïğ bir kend bar erdi (96r7); Meni bu sïğirğa mindürgil senin birlä kentgä barayïn (128v8). It is also possible to observe the situation when the term came in a compound word: Bağdādğa keldilär xalifağa ayttilar: yana qayturda Semüzkent (Самарқанд)gä säkiz yï̆ačlïq yerdin kečib keldük tedilär (176r7). In the works of Alisher Navoi, the meanings of "village" and "city" are visible (АНАТИЛ,II,108).

There are different opinions as to which language the word belongs to. For example, some sources state that it belongs to the Sogdian language ${ }^{1}$. Mahmud Kashgari writes about it: The basis for considering the whole of Movarounnahr, from Yankand to the East as Turkish cities is that the names Samarkand, Semizkend, Tashkent-Shash, Ozkend, Tunkend are all

1 Древнетюркский словарь. -Л.: Наука, 1969.-С. $290 ;$ Ўзбек тилининг изохли луғати. -Т.: Ўзбекистон миллий энциклопедияси, 2006. Т.ІІ. -Б.353; Дадабаев Х. Общественно-политическая и социально-экономическая терминология в тюркоязычных письменных памятниках XI-XIV вв. -T.: Ёзувчи, 1991. -C. ; Қораев C. Ўзбекистон вилоятлари топонимлари. $-\mathrm{T}$ : Ўзбекистон миллий энциклопедияси, 2005. -Б. 36. 
CURRENT RESEARCH JOURNAL OF PHILOLOGICAL SCIENCES 2(8): 56-61,

May 2021 DOI: https://doi.org/10.37547/philological-crjps-02-08-13

ISSN 2767-3758

(C)2021 Master Journals

Crossref dof 81 Google

Accepted26 ${ }^{\text {th }}$ August, 2021 \& Published $31^{\text {th }}$ August, 2021

Turkish. Känd means city in Turkish. They built this city and named it. It still is. When the Persians multiplied in these lands, then they were like the cities of the Ajam (III, 164).The above-mentioned data show that the listed lands of Movarounnahr were founded by the Turks, and later the influence of the Persian-speaking people increased there, and the place names were changed to Persian ${ }^{2}$. According to the Dictionary of Uzbek Folk Dialects, the rural version of the term (ЎХШЛ,141) is used in the South Khorezm and Karamurt dialects.

Today, in Surkhandarya dialects, the verb түр means "to stand, to turn". This word was first mentioned in Yusuf Khos Hajib's epic "Qutadg'u bilig": tükätti sözin türdi badï bitig - finished the word, folded the letter and closed it (ДТС,598). It was used in the same sense in Devon: ol bitig türdi - he folded the letter (DLT, II, 13). This lexeme occurs in the sources of the old Uzbek language, in particular, in the works of Alisher Navoi, meaning "to wrap":

Za'fdin örgämči dāmiga yïqïlğač čïrmanïb,

Ul čibindek türmädi har yan tanïmhï aylanïb.

The term čibič (Таржумон,15-10), which means "one-year-old kid", is used in 11th century Turkic sources as čäbišs//čäpiš (MK, I, 349), in "Kitab ulidrok" of Abu Hayyon as čäpiš (41), in the kirgyz language as šïbïš (РСЛ, IV, 1063). The term is currently used in the phonetic variants of Bakhmal, Josh dialects as čibič, I dialects of Sayram, Tulkibosh, Shymkent as čibiš (ЎХШЛ, 360). There is speculation that the term may have been borrowed from IndoEuropean languages. Compare: Persian-Tajik čäpiš, Latin kapeč, Celtic kapečo-s (ИРЛТЯ,120). According to P. Safarov, the term was borrowed from Iranian languages (1972, 13b).

In ancient Turkic monuments (ДТС,211) and in

\footnotetext{
${ }^{2}$ Содиқов Қ. Туркий ёзма ёдгорликлар тили: адабий тилнинг юзага келиши ва тикланиши. -Т.: Тошкент давлат шақшунослик институти, 2006. -Б. 46.

Turkic sources of the XI century, one of the domestic animals was called inäk: ürün inäk bozağulačï bolmïš - the gray cow is born (MK, I, 135). Mahmud Kashgari said that the term also meant "female tortoise" in Oguz. We see the form of inäk in the 14th century Arabic treatises and in the 14th century Khorezm memoirs: bir qul satğïn bir inäk satğïn aldïm (НФ,147а15; Ат-тухфа,7а6; Таржумон,14-19; Абу Хайён,24; Жамолиддин Туркий,12а5; ХШ,105а21; ҚР,48ч17). According to Radlov's dictionary, the zoonim was used in its original meaning in the Black Kyrgyz, Teleut, Tobol, Taranchin, and Usmoni Turkic languages ( РСЛ, I, 1443).Today, the Kashkadarya dialects use the phonetic forms of the инә://инәк, the Bukhara dialects of the ънак, the Samarkand and Surkhandarya dialects of the инак: кәттәмни биттә инә:ләри бориди, хәрил хурма үстийә туғайде(ЎХШЛ,116). According to Sherbak, the origin of the term is the same as the words inän"female camel", inäk- "female dog", and änäk"female". Inä, änä - the word "mother" is the basis for them (ИРЛТЯ,97). According to Е. Sevortyan, inäk // inäk in-en = is formed from the verb "to give birth", "to miss" - with the affix (ä) k or gäk (ЭCC, I, 359). Our research confirms that E. Sevortyan's opinion is correct.

The cultural landscapes of cities and villages - parks, gardens, as well as meadows and fields are inhabited by birds that are best known to all. According to Mahmud Kashgari, the sparrow, which is one of such birds, was called säčä (MK, III, 238) in the Oghuz language. In "Qisasi Rabguziy" we came across the forms säčä // sečä (ҚР, 13ч12-13), sečäk: sečäk čop tashidi (ҚР,43ч3). In At-tuhfa, we observed the phonetic variants of serşä $(24 \mathrm{bm})$, şərşä, şerşä (24b10). In Jamoliddin Turki's "Kitab bulgat" we see the forms serčä (16b3), and in "Tarjumon" we see the Turkmen särčä (10-7). Although the zoonim is not found in the old Uzbek language sources, to this day it has retained its original meaning in the form of сечә in Urgench, Khiva, Xonqa, Hozarasp dialects: азам биләнсечә қонар ту:тлара, гетмә дәп йеғладым 
CURRENT RESEARCH JOURNAL OF PHILOLOGICAL SCIENCES 2(8): 56-61,

May 2021 DOI: https://doi.org/10.37547/philological-crjps-02-08-13

ISSN 2767-3758

(C)2021 Master Journals

Crossref do: 81 Google

Accepted26 ${ }^{\text {th }}$ August, 2021 \& Published $31^{\text {th }}$ August, 2021

алыс йуртлара (ЎХШЛ,237).

The term ancient turkic quğu (МK,III,245; АTтухфа,18б12; ҚР,68v4; РСЛ,II,98 - swan) used in the work "Devonu lug'otit turk" first appeared in the monuments of Orkhon-Enasay: er quğu qušqa soquštï - the earth collided with a swan (ДТС, 464). In the Turkic sources of the XIV century the forms of qu, qavu (ХШ,28б3), ququ (ХШ,73a20) are observed: Havā üzrä berür šunqarğa qunï (Мн,29065). Jamoliddin Turki's book "Kitab ul-bulgat" mentions the form of quv.This zoonim is not present in the old Uzbek language monuments of the later period. Nevertheless, in the Oghuz and Kipchak dialects, quv (ЎХШЛ, 165) is now used in its original sense. The term "qu-qu" is derived from the word imitation of sound (ИФРЗТ, 21). In the modern Uzbek literary language there is a synonym for swan (ЎТИЛ, I, 560). The term oguzic qarïnča meaning "an ant" (Жамолиддин Туркий,15a7; ҚР,0ч12; Таржумон,11-20)) is mentioned in "Devon" in the form of qarïnča (MK, III, 384) // qarïnčaq (MK, I, 460). In the sources of Khorezm of the XIV century we came across the variant of the qarïnča: küč bilä bir qarïnčanï bassan bilki hali ne bolğay alqïnda $(\Gamma, 3364)$. In At-Tuhfa we see the variant of the qarïnčaq (36a2). Radlov noted that the phonetic forms were used qarïnčqa in the Chigatay language, qarïnja in the Crimean language (РСЛ, III, 174), and qarïs̆qa (РСЛ, II, 181) in the Azerbaijani language. Қарынжа is now used in its original meaning in the southern Khorezm dialects (ЎХШЛ,157). In our opinion, the term qarïn is derived from the affix - čačaq with the word ““қорин”, “қурсақ” (DTS, 427).

The term böy ("At-tuhfa", 24b13 - spider) is used in Mahmud Kashgari's dictionary in the phonetic forms böy, bög (MK, III, 154), oguzic bi (MK, III, 224). "Attuhfa" also features bäv (26b13). Although this zoonim does not appear in other sources, it has come down to us in the form of biy (ЎТИЛ, I, 112). Böy in the treatises "Tarjumon" (11-18), "Kitab ul-idrok" (37) and "Kitab ul-bulgat" (15a5) means "scorpion".
This zoonim is now used in the Forish dialect in the form of бөй, meaning "blackbird" (ЎХШЛ, 55). In our opinion, the bi form is the most ancient of the mentioned forms.

In Mahmud Kashgari's "Devonu lug'otit turk", the word ötrük is explained as follows: ötrÿk is cunning, deceitful, cunning, a liar:

Ötrük ötün ağrïlayuyüzgä baqar,

Elkintašubbermiš ašiğbašqaqaqar.

The cunning, lowly, greedy of the lands is left, the guest looks like a thief in front of him, the stranger thanks the guest for what he eats and hits the guest on the head with what he has given (I, 82). At present, the phonetic variants of this word in Uzbek, Qirq, Kungrad dialects, өтүрүк//өтрүк//үөтрик, Surkhandarya, Kungrad dialects as өтрик mean "lie": өтрик сөлләмә, адам боламан десәң (ЎХШЛ,55)

\section{AnAlysis, RESUlts AND DISCUSSION}

In the Urgench, Khiva, and Xonqa dialects, the term "әмгәк" occurs in the sense of "labor": әмгәк чәкмәк (ХШЛ,123). In Mahmud Kashgari's dictionary and the epic Hibat al-Haqoiq, the term is given in the form of еmgäк: emgäк ekindä qalmas - labor does not go to waste (DLT, I, 134); Кӥс̌ емгӓк tegürmä kišigä qalï3. The fact that this lexeme was first mentioned in the Golden Light and Turfan texts can be found in the Ancient Turkic Dictionary (Drevne tyurkskiy slovar): ačmaq suvsamaq emgäki (ДТС, 172). In the works of Alisher Navoi, the same semantics is found: Emgäkdin alarğa ārām yoq (АНАТИЛ, III, 563). The term is formed by adding the affix - $\mathrm{k}$ to the verb emgä- (ДТС, 172), which means "to suffer, to toil."

In "Devonu lug'otit turk", the Oghuz töl lexeme denotes "the calving season of animals, sheep and

3 Мисоллар Қозоқбой Махмудовнининг “Ахмад Югнакийнинг "Хибатул хақойиқ” асари хақида" китобида келтирилган матндан олинди (Тошкент: Фан, 1972). 
CURRENT RESEARCH JOURNAL OF PHILOLOGICAL SCIENCES 2(8): 56-61,

May 2021 DOI: https://doi.org/10.37547/philological-crjps-02-08-13

ISSN 2767-3758

(C)2021 Master Journals

Crossref do: 81 Google

Accepted26 ${ }^{\text {th }}$ August, 2021 \& Published $31^{\text {th }}$ August, 2021

goats." At the same time, the dictionary notes that the word is also applied to the child. In the Oghuznama, the word tölboğaz is combined with the word "pregnant" and means "pregnant": töl boğaz boldï

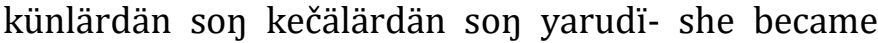
pregnant, and after days and nights, she gave birth (ДТС, 579). Zoonim töl continues its semaphore in Samarkand, Kashkadarya and Surkhandarya dialects: бъзәдә төл омбешънчъ мәртләрдәдоржъ чүшәдъ(ЎХШЛ,261).

Today, in Surkhandarya dialects, the word алқынды is used to refer to the remnants of laundry soap. This lexeme is found in Mahmud Kashgari's "Devonu lug'otit turk", which is considered to be the source of the Karakhanid period, in the following senses: a) to be completed: alqïndï nän; b) to die: eralqïndï (ДЛТ, I, 255); c) "to lose, to extinguish": yalïnuq urulmïš qap ol, ağzï yazïlïb alqünur - a human child is like an inflated mesh; when the mouth is opened, the hand loses it, extinguishes it (ДЛТ, I, 204).

In "Devonu lug'otit turk", the verb az means "to go astray": ol yol azdï - he went astray (ДЛТ, I, 184). This word is first observed in the Turfan texts: yol azsar ev tapmaz - he does not find his lost home (ДТС, 72). It is also used in the sources mentioned in the XIV century sources: Tā qaysï ariilğ tiynatlïg yoldïy azmï̌ bolğay (АНАТИЛ,II,506).The term under study is currently used in Surkhandarya dialects in the semantics of "going astray" (СЎШЛ, 15).

In Mahmud Kashgari's "Devonu lug'otit turk", a loaf of bread baked on a coffin is called kömäč (ДЛТ, I, 341). It is also mentioned on page 51 of the work that the word is derived from the verb komdi. Alisher Navoi's works also contain the following semantics: Yana tutmač va umač va kөmäč va talğannï türkčä ayturlar (АНАТИЛ,II,151). The word under investigation is still used in Surkhandarya dialects. The lexeme ет/эт(ЎХШЛ,95), which means "meat", "soft part of the human body, muscles" in the dialects of South Khorezm, Naiman, Namangan, Kirk, Surkhandarya, first appears in "Devonu lug'otit turk". The following semantics can be seen in the play: a) "meat": toğray män - (ДЛТ,III,326); b) "surface of the body, skin":

Qiiš yayğaru suvlanur

Er et menin yavrulur

İglär yemä savrïyur

Et yin taqï bekrišür - describing the debate between summer and winter, he says that the skin and the surface of the bodies of people and animals are healed and strengthened in me. Patients are reduced in winter. People's bodies and skins mature and become strong (ДЛТ, IІІ, 294): c) "body, skin": etim qiičidï - my body itches (ДЛТ, III, 275); g) "soft": et yer - soft earth (ДЛТ, I, 70).

\section{Conclusion}

Apparently, despite the fact that for a long time in the middle, most of the words involved in the comparative analysis (ayak, känd, čäbiš, inäk, säčä, quğu, qarinča, töl,) are not used in the Uzbek literary language today, but are used in our dialects. Some (böy, alqïndï, ötrük) have undergone a change in meaning, and some are used in modern literary language with minor phonetic changes (avut, az). This, in turn, indicates that our language, dialects, the history of our people go back to ancient times.

\section{LIST OF ACRONYMS}

Абу Хайён - Расулова Н.А. Исследования языка “Китаб ал-идрак ли-лисан ал-атрак” Абу Хаййана, Морфология, лексика и глоссарий: Дисс, канд. Филол. наук.-Ташкент, 1969.

АНАТИЛ - Алишер Навоий асарлари тилининг изохли луғати . I-IV. - Тошкент: ФАН, 1983-1985.

Ат-тухфа - Изысканный дар тюркскому языку: Грамматический трактат XIV в на арабском языке/Введение, лексико-грамматический очерк, перевод, грамматический указатель. Э.И. Фазылова и М.Т. Зияевой. -Ташкент, 1978. 
CURRENT RESEARCH JOURNAL OF PHILOLOGICAL SCIENCES 2(8): 56-61,

May 2021 DOI: https://doi.org/10.37547/philological-crjps-02-08-13

ISSN 2767-3758

(C)2021 Master Journals

\section{Crossref do) 81 Google}

Accepted $26^{\text {th }}$ August, 2021 \& Published $31^{\text {th }}$ August, 2021

Г - Сайфи Сарайи. Гулистан бит-турки//Фазылов

Э. Староузбекский язык. Хорезмийские памятники XIV века. I-II-Ташкент: ФАН, 19661971.

ДТС - Древнетиюркский словарь. -Л.: Наука, 1969. Жамолиддин Туркий - Файзуллаева Ш.А. Исследование языка памятника XIV в. "Китабу булғат ал-муштақ фи луғат ат -турк ва-л қифчақ" Джамалад - Дина ат-Турки: Дисс.канд. филол.наук. - Ташкент, 1969.

МК - Махмуд Қошғарий, Девону луғотиттурк/Таржимон ва нашрга тайёрловчи C.M. Муталлибов. Т. I-III. - Тошкент: ФАН, 1960-1963.

Мн - Хорезми. Мухаббат-наме//Фазылов Э.Страузбекский язык. Хорезмийские памятники XIV века. I-II. -Ташкент: ФАН, 1966-1971.

НФ - Нахджул - фарадис / / Фазылов Э.Староузбекский язык. Хорезмийские памятники XIV века. T. I-I. -Ташкент: ФАН, 1966-1971.

РСЛ - Радлов В.В. Опыт словаря тюркских наречий. I-IV. -СПБ, 1893-1911.

СЎШЛ - Рахимов С. Сурхондарё ўзбек шевалари луғати. - Термиз, 1995.

Тафсир - Бороков А.К. Лексика среднеазиатского тефсира XII-XIII BB.-М.: Изд-во восточной лит-ры, 1963.

ХШ - Кутб. Хосров и Ширин // Фазылов Э. Староузбекский язык. Хорезмийские памятники XIV века. T. I-II. Ташкент: ФАН, 1966-1971.

ЭСС - 1) Севортян Э.В. Этимологический словарь тюркских языков: Обшетюркские и межтюркские основы на гласные. -М.: Наука, 1974-.

2) Севортян Э.В. Этимологические словарь тюркских языков: Обшетюркские и межтюркские основа на букву “Б”. -М.: Наука, 1978.

3) Севортян Э.В. Этимологические основы на буквы “В”, “Г”, “Д”. - М.: Наука, 1980.

ЎТИЛ - Ўзбек тилининг изохли луғати. I-II. Русский язык, 1981.

ЎХШЛ - Ўзбек халқ шевалари луғати. - Тошкент: ФАН, 1971.

ҚР - 1) Н.Б. Рабғузий. Қиссаси Рабғузий. I-II Тошкент: Ёзувчи, 1990-1991.
2) Rabqhyzi. Narrationes de Prophetis. Reproduced in facsimile. Wirt an introductions by K. Gronbech. Copenbech. 1948.

3) Nasirud-din bin burhayud-din din Rabquz. KisasulEnbiya. II. Dizin. Aysu Ata. - Ankara, 1997.

\section{ReFERENCES}

1. Баскаков Н.А. Русские фамилии тюрского происхождения. -М : Наука,1979. -С. 218.

2. Дмитриев Н. К. Строй тюркских языков. М., 1962. -С. 164.

3. Ефремова Т. Современный толковый словарь русского языка. - Москва, 2005. -С. 267.

4. Исхоқов М., Содиқов Қ., Омонов Қ. Мангу битиглар. -Тошкент, 2009. -Б. 103.

5. Каримуллина Г.Н. Тюрские лексические елементы в русской лингвографии XVIII-XX веков. Дис. канд. филол. наук. -Казан,2007.

6. Комлев Н. Словарь иностранных слов. -М., 2006. -С. 258.

7. Коркмазова Л.М. Освоение в русском языке тюркизмов с неясными основами :Дис. канд. филол. Наук. - Махачкала, 2004.

8. Қодиров П. Тил ва эл. - Т., 2005. -Б. 258.

9. Рустамов А. Сўз хусусида сўз.-Тошкент: EXTREMUMPRESS, 2010. - Б.96.

10. Сагидуллин М. А. Тюркские этнонимы в русской топонимии Юга Тюменской области :Дис. канд. филол. Наук.-Тюмень, 2002.

11. Шипова Е.Н. Словарь тюркизмов в русском языке. -Алма-Ата, 1976. -С. 314.

12. Эшқобил Шукур. Бобо сўз изидан. - Тошкент: MASHHUR-PRESS, 2018.-Б.191.

13. Юналеева Р.А. Тюркизмы в русском языке: (на материале названий одежды): Автореф. дис. д-ра филол. наук.-М., 1985.

14. https://www.bbc.com/uzbek/lotin-37144340. 